\title{
INTRODUKSI TEKNOLOGI AERASI TERBARUKAN PADA KELOMPOK PEMBUDIDAYA IKAN PATIN DI KJA WADUK SAGULING, KECAMATAN CILILIN
}

\author{
Zahidah, Iskandar, Ujang Subhan dan Yuli Andriani \\ Staf pengajar program studi perikanan, Fakultas Perikanan dan Ilmu Kelautan, Universitas Padjadjaran \\ Email: ibuzah@gmail.com
}

\begin{abstract}
ABSTRAK. Program Pengabdian pada masyarakat ini bertujuan belajar sambil bekerja atau mempraktekkannya (learning by doing). Pengabdian diselangarakan di kelompok pembudidaya ikan patin dalam karamba jaring apung (KJA) yang merupakan kelompok binaan PKBM Alkaromah, Kecamatan Cililin Bandung Barat. Program yang ditawarkan berjudul Introduksi Teknologi Aerasi Terbarukan pada Kelompok Pembudidaya Ikan Patin di KJA Waduk Saguling, Kecamatan Cililin. Kegiatan dilaksanakan dengan diawali Identifikasi potensi sumberdaya alam dan sumberdaya manusia, hambatan yang dihadapi pembudidaya, sosialisasi teknologi aerasi kepada kelompok sasaran, penyuluhan dan pendampingan. Adapun hasil yang didapatkan adalah telah terpasangnya sebuah instalasi aerasi terbarukan dengan teknologi fine bubbles pada KJA ikan patin di Waduk Saguling.
\end{abstract}

Kata kunci: ikan patin; fine bubbles; KJA; Waduk Saguling

ABSTRACT. This Community Service Program aims to learn while working or practicing (learning by doing). Devotion is held at the patin fish farmers group in floating net cage culture (FNCA) in Saguling Reservoir, which is a PKBM Alkaromah fostered group, in Cililin District, West Bandung. The program offered is entitled Introducing Renewable Aeration Technology at the Patin Fish farmers Group in Saguling Reservoir, District of Cililin. The activity was carried out by beginning with the identification of the potential of natural resources and human resources, problems faced by farmers, dissemination of aeration technology to the target groups, counseling and assistance. The results obtained are the installation of a renewable aeration installation with fine bubbles technology in the Floating Net Cages Aquaculture of patin fish in Saguling Reservoir

Key words: patin fish; fine bubbles; FNCA; Saguling Reservoir

\section{PENDAHULUAN}

Penelitian mengenai pemanfaatan teknologi aerasi bersumber energi terbarukan telah dilakukan oleh tim pelaksana pengabdian baik di laboratorium, maupun di KJA Waduk Cirata (Hasan, Masjamsir dan Iskandar, 2015). Rangkaian penelitian ini ditujukan untuk memecahkan salah satu masalah yang dihadapi oleh pembudidaya ikan dalam Karamba Jaring Apung (KJA), yaitu rendahnya konsentrasi oksigen di lokasi tersebut, yang secara langsung akan berpengaruh terhadap kehidupan ikan-ikan yang dibudidayakan. Aplikasi teknologi aerasi dilakukan mengingat beberapa hasil penelitian menunjukkan konsentrasi oksigen pada petak-petak KJA terutama pada malam hari relatif rendah (di bawah konsentrasi optimal). Hasil penelitian menunjukan bahwa aplikasi teknologi aerasi dengan memanfaatkan energi matahari mampu meningkatkan konsentrasi oksigen terlarut di petakpetak KJA. Peningkatan konsentrasi oksigen terlarut tersebut memicu nafsu makan ikan, sehingga ikan yang dipelihara di petak-petak tersebut tumbuh lebih cepat. Pemahaman untuk menjaga kualitas air waduk agar tetap berada pada kondisi optimalnya seharusnya sudah dimulai diperkenalkan kepada masyarakat sedari dini dan tidak hanya dilakukan di badan air itu sendiri, namun juga dilakukan di ekosistem terestrial. Upaya untuk menjaga kualitas air di ekosistem terrestrial dan oleh masyarakat pada usia remaja sudah diinisiasi diantara oleh Herawati dkk (2019) yang melakukan penyuluhan pemilahan sampah domestic sebagai peningkatan kesadaran siswa
SMP di Darmaraja, Kabupaten Sumedang sebagai upaya untuk menjaga kualitas air Waduk Jatigede.

Secara umum sudah diketahui bahwa oksigen berpengaruh terhadap laju pada proses metabolisme ikan. Salah satu penyebab utama menurunnya produktivitas ikan adalah konsentrasi oksigen terlarut (Disolved Oxygen, DO) yang rendah. Fine Bubble (FBs) adalah gelembung kecil yang berukuran mikro dengan diameter 200 nanometer hingga 100 mikrometer (Serizawa 2017). Keunikan karakteristik gelembung mikro merupakan akibat dari adanya peristiwa tegangan permukaan $(\gamma)$ yang lebih tinggi dibandingkan gelembung biasa. Sehingga dapat berpengaruh pada diameter gelembung yang dihasilkan (d). Tegangan permukaan yang dimaksudkan tersebut dapat dinyatakan dalam bentuk persamaan Young-Laplace yang mendeskripsikan perbedaan antara tekanan di dalam $(\mathrm{Pg})$ dan di permukaan $(\mathrm{P} \ell)$ gelembung gas tunggal dalam bentuk sperikal.

Aplikasi teknik Fine Bubbles (FBs) pada sistem budidaya digunakan untuk meningkatkan konsentrasi gas terlarut (oksigen) dalam air sehingga memberikan efek positif seperti pertumbuhan ikan yang lebih cepat, ikan tidak mudah terserang penyakit, dan kualitas air tetap terjaga meski dalam sistem kolam tertutup (air disirkulasi terus menerus, termasuk sistem akuaponik) (Fadhillah 2016). Karena diameternya yang kecil, FBs menghadirkan tekanan internal yang tinggi dan laju perpindahan massa yang cepat, yang secara signifikan dapat meningkatkan kelarutan gas, dibandingkan dengan gelembung normal. FBs memiliki kecepatan naik yang lebih rendah dalam 
fase cair, gelembung ini dapat bertahan dalam air hingga waktu yang lama (Seddon et al.,.dalam Hu dan Xia 2017). Hasil yang diharapkan dari penelitian ini adalah berupa teknologi tepat guna berupa "finebubbles" yang diyakini memiliki kelebihan dibandingkan teknologi aerasi lainnya sebagai pemasok oksigen pada lokasi-lokasi KJA.

Fine bubbles (FBs) merupakan generator/aerator bubble yang saat ini menjadi rujukan untuk diaplikasikan sebagai sumber aerasi dalam kegiatan budidaya ikan. Teknologi fine bubbles memiliki keunggulan dalam meningkatkan konsentrasi oksigen terlarut, dapat mengapungkan partikel tersuspensi, permukaan partikel bubble memiliki kemampuan sebagai anti mikroba (Serrizawa, 2017). Subhan et al., (2017) menguji fine bubble produksi lab Nanoteknologi dan Graphene, Unpad dengan kapasitas 125 watt mampu meningkatkan oksigen terlarut sebesar $0.455 \mathrm{ppm} / \mathrm{detik} / \mathrm{L}$ dan zona hambat bakteri Aeromonas hydrophylla sebesar 1,76 $\mathrm{mm}$ pada hari pertama dan 1,92 mm pada hari kedua.

Kegiatan PPM integratif ini merupakan sebuah bentuk pertanggungjawaban peneliti kepada stakeholder utama perikanan, yaitu pembudidaya. Dipilihnya ikan patin dalam kegiatan ini mengingat saat ini pembudidaya di Waduk Saguling lebih memilih ikan patin sebagai ikan budidaya yang relatif lebih tahan perubahan lingkungan dibandingkan ikan-ikan budidaya lainnya. Dengan melihat kondisi kualitas air di Waduk Saguling yang sangat fluktuatif, maka permasalahan yang dihadapi oleh kelompok pembudidaya ikan patin di Waduk Saguling dirasa lebih sesuai untuk diselesaikan dengan memperkenalkan instalasi finebubbles.

Introduksi teknologi ini terkait dengan perilaku penerimaan pembudidaya ikan. Teknologi ini diharapkan dapat diterima oleh pembudidaya ikan dalam meningkatkan konsentrasi oksigen dan produktivitas KJA serta meminimalkan kemungkinan kematian massal ikan yang sampai saat ini masih merupakan masalah yang belum terselesaikan akibat turn over. Agar aplikasi teknologi aerasi ini dapat diterima oleh pembudidaya ikan, perlu dilakukan sosialisasi kepada lebih banyak pembudidaya agar adopsi teknologi aerasi dapat terjadi dalam waktu yang cepat. Skema kerangka pemecahan masalah ditampilkan pada Gambar 1.

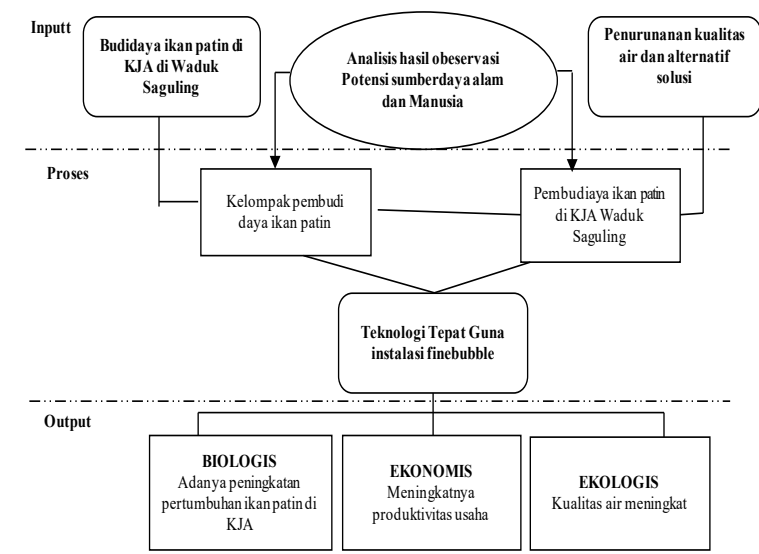

Gambar 1. Skema kerangka pemecahan masalah yang ditawarkan

\section{METODE}

Metode yang digunakan dalam kegiatan ini terdiri dari penyuluhan, substitusi ipteks dan pendampingan serta monitoring pasca pemasangan alat. Metode penyuluhan ditujukan untuk meningkatkan pemahaman kelompok sasaran mengenai pentingnya mengaplikasikan teknologi yang ditawarkan untuk mempertahankan, bahkan meningkatkan produktivitas usaha tani mereka. Sebelum kegiatan ini dilaksanakan dilakukan observasi dan pemetaan keinginan/kebutuhan kelompok sasaran. Kelompok sasaran dalam kegiatan PPM Integratif ini adalah kelompok pembudidaya KJA di Waduk Saguling yang membudidayakan ikan patin yang berlokasi di Kecamatan Cililin, Kabupaten Bandung Barat. Kelompok sasaran merupakan pengusaha mikro bidang perikanan. Hasil yang diharapkan dari kegiatan penyuluhan adalah meningkatnya pemahaman kelompok sasaran mengenai teknologi yang ditawarkan.

Tahapan kegiatan selanjutnya adalah memperkenalkan alat aerasi berteknologi fine bubbles serta memberikan pelatihan dan pendampingan pemasangan alat. Tujuan dari tahapan ini adalah untuk memperkenalkan alat fine bubble, serta manfaatnya untuk meningkatkan kualitas air, terutama konsentrasi oksigen terlarut yang menjadi permasalah utama dalam budidaya KJA, termasuk dihadapi oleh kelompok sasaran.

Tahapan akhir dari kegiatan PPM integratif adalah pendampingan dan monitoring pasca alat terpasang. Pendampingan dan monitoring pasca pemasangan instalasi ditujukan untuk memastikan alat yang dipasang berfungsi dengan optimal dan memberikan hasil sesuai yang diharapkan.

Kegiatan PPM Integratif ini dilaksanakan oleh narasumber pertama yang memiliki kompetensi dalam mengelola kualitas air dan mampu memberikan informasi pentingnya menjaga kualitas air. Narasumber kedua memiliki kompetensi dalam teknologi aerasi fine bubbles. Sehingga kegiatan ini dapat dipertanggungjawabkan secara akademis.

\section{HASIL DAN PEMBAHASAN}

Kegiatan penyuluhan yang merupakan kegitan pertama yang dilaksanakan dengan tujuan untuk meningkatkan wawasan kelompok sasaran. Materi yang disampaikan adalah kegiatan penyuluhan ini meliputi kualitas air dan pengaruhnya terhadap pertumbuhan dan kelangsungan hidup ikan yang disampaikan oleh Ibu Zahidah serta materi pengenalan alat aerasi berteknologi fine bubbles yang disampaikan oleh Bpk. Ujang Subhan. Penyuluhan ini diikuti oleh kelompok pembudidaya ikan patin sebanyak 21 orang, Pembina kelompok (ketua kelompok PKBM Alkaromah), serta mahasiswa KKNM Intergratif yang merupakan bagian tak terpisahkan dari kegiatan PPM Integratif ini. Acara penyuluhan ini dilaksanakan pada Hari 
Kamis 25 Juli 2019. Dokumentasi kegiatan penyuluhan diperlihatkan pada Gambar 2. Peserta penyuluhan sangat antusias mengikuti kegiatan ini. Hal tersebut terlihat dari keseriusan mereka mendengarkan paparan dari pemateri, serta terlibat dalam diskusi yang menunjukkan mereka membutuhkan materi-materi tersebut serta menginginkan alat yang ditawarkan untuk dipasang di KJA mereka. Antusiame peserta penyuluhan dipicu oleh kebutuhan mereka dalam menyelesaikan masalah yang mereka hadapi serta konsep teknologi yang ditawarkan dapat dijangkau oleh peserta pelatihan. Kondisi yang sama dikemukakan oleh Zidni dkk (2018) yang menawarkan teknologi kolam terpal yang dipasang di pekarangan rumah sebagai upaya pemenuhan kebutuhan hewani masyarakat dengan keterbatasan lahan di Desa Cipacing, Kecamatan Jatinangor, Kabupaten Sumedang.

Setelah dipaparkan materi oleh masing-masing pemateri dilanjutkan dengan diskusi. Dalam diskusi tersebut terlihat kelompok sasaran sangat merespon dan menginginkan teknologi tersebut untuk diaplikasikan di KJA mereka. Hal ini tentu saja perlu untuk ditindaklanjuti mengingat teknologi ini diperkirakan akan memberikan hasil yang menguntungkan kelompok pembudidaya. Hasil yang lebih baik akan diperoleh berupa kualitas air yang meningkat melalui peningkatan konsentrasi oksigen terlarut, yang diyakini memiliki "domino efek" positif berupa penurunan senyawa-senyawa beracun, peningktan nafsu makan ikan dan tentu saja semua ini akan berdampak pada peningkatan produktivitas budidaya. Tentu saja peningkatan produktivitas budidaya diharapkan memberikan peningkatan pendapatan.

Kegiatan kedua yang dilaksanakan adalah pemasangan dan instalasi alat aerasi berbasis teknologi fine bubbles (FBs). Dalam kegiatan penyuluhan disepakati bahwa alat akan dipasang di KJA ketua kelompok, yaitu Bpk. Danil Aripin yang terletak di blok Sayuran, Desa Mekar Mukti, Kecamatan Cililin. Alat yang ditawarkan sebagai salah satu solusi untuk mengatasi masalah penurunan kualitas air, terutama konsentrasi oksigen terlarut merupakan alat yang dikembangkan oleh Pusat Riset Institusi Nanoteknologi dan Graphen (PrintG) Universitas Padjadjaran. Pemasangan dan instalasi alat ini dilakukan bersama-sama oleh kelompok sasaran didampingi oleh mahasiswa KKNM serta diawasi oleh Bpk. Ujang Subhan sebagai peneliti finebubbles. Dokumentasi kegiatan pemasangan dan instalasi alat finebubbles ditampilkan pada Gambar 3

Sebagai salah satu bentuk pertanggungjawaban peneliti dan pelaksana PPM Integratif ini serta untuk meningkatkan motivasi kelompok untuk mengaplikasikan alat ini, maka tim pelaksana PPM Integratif menghibahkan satu unit alat finebubbles kepada kelompok sasaran.

Kegiatan pendampingan dan monitoring pasca pemasangan alat. Kegiatan ini ditujukan untuk memastikan alat berfungsi dengan baik dan memberikan hasil sebagaimana yang diharapkan. Berdasarkan hasil

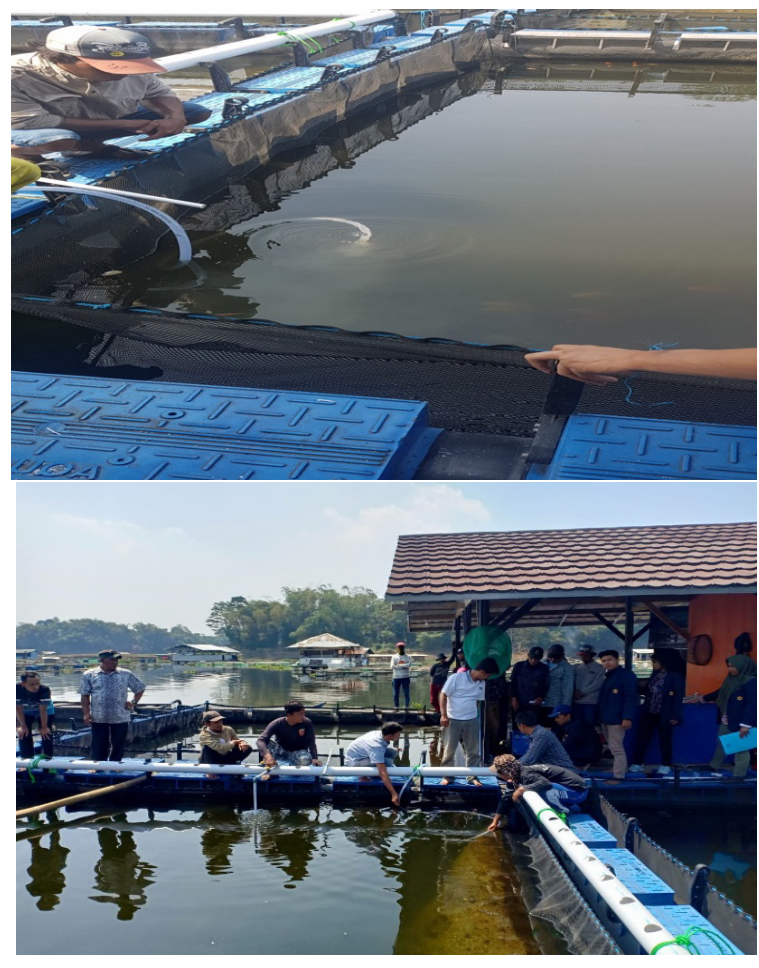

Gambar 3. Kegiatan pemasangan instalasi alat finebubbles

monitoring, diperoleh informasi bahwa alat tersebut berfungsi dengan baik, mampu meningkatkan konsentrasi oksigen terlarut dalam air. Diharapkan dengan meningkatnya oksigen terlarut dalam air, maka kejadian kematian massal ikan yang dibudidayakan yang sering terjadi, terutama pada musim hujan dapat diminimalkan. Namun demikian peningkatan produksi dan produktivitas sebagaimanayang diharapkan belum dapat diinformasikan, mengingat budidaya masih berlangsung.

\section{SIMPULAN}

Program PPM Integratif yang ditujukan pada kelompok sasaran pembudidaya ikan patin dalam KJA di Waduk Saguling meningkatkan kelompok sasaran dalam pemahaman peran kualitas air terutama oksigen terlarut dalam budidaya ikan patin, terutama budidaya di KJA. Antusiasme peserta pelatihan menunjukkan kelompok sasaran merasa membutuhkan solusi untuk permasalahan yang mereka hadapi dalam usaha mereka. Aplikasi teknologi finebubbles diyakini dapat menjadi salah satu alternatif dalam menyelesaikan masalah yang mereka hadapi.

\section{UCAPAN TERIMA KASIH}

Kegiatan ini terselenggara dengan adanya program riset dan PPM dengan sumber dana Hibah Internal Unpad (HIU). Untuk itu tim pelaksana PPM integrative mengucapkan terima kasih kepada Direktorat Riset Pengabdian Pada Masyarakat dan Inovasi, Universitas Padjadjaran. Terima kasih juga disampaikan kepada PKBM Al Karomah serta kelompok pembudidaya ikan 
patin dalam KJA di Blok Sayuran, Desa Mekar Mukti, Kecamatan Cililin, Kabupaten Bandung Barat.

\section{DAFTAR PUSTAKA}

Fadhillah, M. 2016. The Future of Biotechnology and Nano Biotechnology. Department of Bioscience and Biotechnology, Kyushu University, Japan.

Hasan, Z, Masjamsir dan Iskandar. 2015. Pemanfaatan Teknologi Aerasi Berbasis Energi Surya untuk Memperbaiki Kualitas Air dan Meningkatkan Pertumbuhan Ikan Nila di KJA Waduk Cirata. Jurnal Akuatika 6(1) 68-78

Herawati, H., Kurniawati, N., Maulina, I., Hasan, Z., Sahidin,A., Apriliani, I.., dan Dewanti, L.P. 2019. Penyuluhan Pemilahan Sampah Domestik Sebagai Peningkatan Kesadaran Siswa dalam Usaha Menjaga Kualitas Air Waduk Jatigede di SMP Negeri 2 Darmaraja, Kabupaten Sumedang. Dharmakarya 8(2) 111-114
Hu, L. dan Xia Z. 2017. Application of Ozone Micro-NanoBubbles to Groundwater Remediation. Journal of Hazardous Materials 342. pp 446-453.

Serizawa. A. 2017. Fundamentals and Applications of Micro/Nano Bubbles. Internasional Symposium on Application of High Voltage, Plasmas and Micro/ Nano Bubbles to Agriculture and Aquaculture,5-7 January 2017. Rajamangala University of Technology Lanna Chiang Mai. Thailand

Subhan, U.,V. Muthukannan, S.Y. Azhary, M.F. Mulhadi, E. Rochima, C. Panatarani, I. M. Joni. Development and Performance Evaluation of Air Fine Bubbles on Water Quality of Thai Catfish Rearing. The 1st International Conference and Exhibition on Powder Technology Indonesia (ICePTi). Jatinangor, Indonesia 8-9 August 2017.

Zidni,I., Andriani,Y., Zahidah dan Setiawan. 2018. Pemanfaatan Pekarangan Rumah Sebagai Penyedia Protein Hewani melalui Budidaya Lele Kolam Terpal di Desa Cipacing, Jatinangor, Sumedang, Jawa Barat. Dharmakarya 7(4) 248-251 